\title{
Retired consultants and other career grade psychiatrists returning to work in the NHS
}

\author{
Department of Health
}

At present there are still a large number of unfilled consultant posts in most psychiatric disciplines in both England and Scotland. The Department of Health is understandably keen to encourage recently retired consultants and other career grade staff to work either part-time or fulltime in these posts until adequate numbers of specialist registrars who have completed specialist training are available to fill them. The following description of the NHS pension scheme rules for the medical work force has been provided by the Department of Health with this end in view.

\section{NHS Pension Scheme Rule Medical Worlforce}

Pensions are intended to provide a regular income in retirement to help replace the wages or salary people have relied on during their working life. In the NHS, pension scheme members may retire at age 60, the scheme's normal retirement age, and enjoy a pension and lump sum based on their scheme membership and final salary.

At one time, provided they had a break in employment of at least 24 hours, scheme members could take their pension benefits from age 60, rejoin the scheme in further NHS employment and earn additional pension benefits. This might appear attractive but it presented problems for both the scheme and the member.

From the purist's point of view, these provisions rather defeated the concept of pensions being replacement income in retirement. In practical terms, they increased scheme complexity and caught members under the public service abatement rules. Pensions in payment could be reduced in re-employment if, when added to the pension rate, earnings exceeded pre-retirement income. From 6 March 1995, therefore, as part of an overall restructuring package, the scheme changed its retirement and abatement rules.

The new arrangements are geared to members deciding when it is best for them to retire permanently on or after age 60 and take their pension benefits. There should be an intention to retire, not just to take a temporary break in employment. That said, the new retirement rules include some flexibility to cover situations where it is necessary for experienced staff to continue to work in a limited capacity, for example to cover short term absences or vacancies.

From 6 March 1995, therefore, before pension benefits can be paid on retirement, there must be a definite break in employment. If scheme members return to NHS employment within one month of retirement, their pension benefits will be suspended unless the re-employment is for no more than 16 hours a week and started at least 24 hours after retirement.

After a month no limit is applied to the hours that can be worked.

As the intention is that age-related pension benefits should only be paid at final retirement. periods of re-employment starting on or after 6 March 1995 are not pensionable in the scheme. While NHS pensioners may not be able to rejoin the pension scheme and earn additional pension benefits, the scheme has abolished the abatement rule, under which pensions could be reduced, for those over age 60 .

The new retirement rules allow scheme members choice and flexibility over their retirement date, without limiting the ability of NHS employers to recruit newly retired, experienced staff for short-term, part-time employment in the interests of patient services.

These are complex technical matters. Pension scheme members are advised always to check with the NHS Pensions Agency or their employing authority before making decisions about their retirement, particularly if there is the possibility of further re-employment. 